九州大学学術情報リポジトリ

Kyushu University Institutional Repository

\title{
Freatures and Trends of Rainfall in Recent 20 Years at Different Locations in Humid Tropical to Subtropical Asia
}

Egashira, Kazuhiko

Laboratory of Soil Science, Division of Soil Science and Plant Production, Dpartment of Plant Resoruces, Faculty of Agriculture, Kyushu University

Matsushita, Yousuke

Laboratory of Soil Sciencd, Program of Agricultural Chemistry, Course of Applied Biological

Science, Department of Bioresource and Bioenvironment, School of Agriculture, Kyushu University

Virakornphanich, Prasop

Training Center for Agricultural Development

Darmawan

Department of Soil Science, Bogor Agricultural University

他

https://doi.org/10.5109/4545

出版情報: 九州大学大学院農学研究院紀要. 48 (1/2)，pp.219-225，2003-10-01. Faculty of Agriculture, Kyushu University

バージョン :

権利関係 : 


\title{
Features and Trends of Rainfall in Recent 20 Years at Different Locations in Humid Tropical to Subtropical Asia
}

\author{
Kazuhiko EGASHIRA ${ }^{\dagger}$, Yousuke MATSUSHITA*, \\ Prasop VIRAKORNPHANICH**, DARMAWAN***, \\ Abu Zofar Md. MOSLEHUDDIN $* * * *$, \\ Md. Abdullah Al MAMUN**** \\ and DO Nguyen Hai ${ }^{* * * * *}$ \\ Laboratory of Soil Science, Division of Soil Science and Plant Production, \\ Department of Plant Resources, Faculty of Agriculture, \\ Kyushu University, Fukuoka 812-8581, Japan \\ (Received May 26, 2003 and accepted July 15, 2003)
}

\begin{abstract}
Monthly rainfall data of the last 20 years were obtained for 16 locations in Thailand, and for 7,4 , and 1 location(s) in Indonesia, Bangladesh, and Viet Nam, respectively, under tropical to subtropical monsoon and tropical rainforest climates. They were used to calculate the average and variability of rainfall at those locations and to examine the recent rainfall trend by application of the first regression analysis. The rainfall trend, expressed as a regression coefficient of the first regression equation, was only significant at some locations, but the positive rainfall trend was identified at locations in Peninsula Thailand, whereas the negative rainfall trend was indicated for locations in Sumatra and Java Islands of Indonesia. At locations under tropical to subtropical monsoon climate, the significant trends in the annual and seasonal rainfall were hardly indicated, but the large annual variability of rainfall was observed in the dry-season.
\end{abstract}

Key words: monsoon Asia, rainfall, rainfall trend, rainfall variability.

\section{INTRODUCTION}

Rainfall is the most important agricultural resources in the tropics and subtropics. The amount and distribution of rainfall in a year fundamentally control land use and cropping patterns in the regions. However, annual and seasonal or monthly rainfall varies considerably with years. As a result, the rainfall trend is a current concern by researchers, administrators, and farmers (Ohno et al., 2002). In the previous papers (Egashira and Karim, 2001; Egashira, 2002), a decreasing tendency of the annual and dry-season rainfall was recognized by the data recorded at the meteorological station of Bangabandhu Sheikh Mujibur Rahman Agricultural University, located in the center of the Pleistocene

* Laboratory of Soil Science, Program of Agricultural Chemistry, Course of Applied Biological Science, Department of Bioresource and Bioenvironment, School of Agriculture, Kyushu University

** International Training Center for Agricultural Development, Khon Kaen 40000, Thailand

*** Department of Soil Science, Bogor Agricultural University, Bogor, Indonesia

**** Department of Soil Science, Bangladesh Agricultural University, Mymensingh-2202, Bangladesh

***** Department of Soil Science and Agrochemistry, Faculty of Land and Environment, Ha Noi Agricultural University, Gia Lam, Ha Noi, Viet Nam

+ Corresponding author (E-mail: kegashi@agr.kyushu-u.ac.jp) 
Madhupur Tract of Bangladesh. In the present study, monthly rainfall data recorded at different locations during the last 20 years in Thailand, Indonesia, Bangladesh, and Viet Nam were collected. Features (amount and variability) of the annual and seasonal rainfall were clarified and the recent trends of rainfall were examined by application of the first regression analysis to the collected data.

\section{MATERIALS AND METHODS}

\section{Locations and rainfall data collection}

Locations where rainfall data were collected are listed in Tables 1 through 3, with their latitude and longitude and the duration of available data. Rainfall data of 16 locations throughout the country were collected in Thailand, and those of Indonesia came from 7 locations in the main 3 islands. Four big cities are locations for data collection in Bangladesh, and only the data of Ha Noi were collected in Viet Nam. The rainfall data in Thailand, Indonesia, Bangladesh, and Viet Nam were collected through Prasop Virakornphanich (International Training Center for Agricultural Development at Khon Kaen), Darmawan (Bogor Agricultural University), Abu Zofar Md. Moslehuddin and Md. Abdullah Al Mamun (Bangladesh Agricultural University), and Do Nguyen Hai (Ha Noi Agricultural University). The data were taken as monthly rainfall but were partly missing at some locations.

\section{Statistical analysis}

The average and coefficient of variation of annual rainfall at different locations were calculated from the collected monthly rainfall data. First regression analysis was applied to examine the rainfall trend, and the significance of the regression coefficient was verified by assuming fitting of rainfall data to the t-distribution. In addition to annual rainfall, in Thailand, Bangladesh, and Viet Nam of the northern hemisphere, analysis was made to 3 cropping seasons of the dry (November to February for Thailand and November to March for Bangladesh and Viet Nam), premonsoon (March to May for Thailand and April to May for Bangladesh and Viet Nam), and monsoon (June to October) seasons. However, subdivision to the 3 seasons is only applicable to the locations under monsoon climate. In Indonesia of the southern hemisphere, analysis was made to the 2 seasons of April to September and of October to March.

\section{RESULTS AND DISCUSSION}

The average and coefficient of variation of rainfall, and the regression coefficient of the first regression equation between the rainfall amount and the year are given in Tables 1 through 3.

\section{Thailand}

Results for Thailand are given in Table 1. The north and northeast divisions of Thailand are under tropical monsoon climate (Kawaguchi and Kyuma, 1977; Region V according to their climatic region). Mean annual rainfall of 11 locations of these divisions ranged from $833 \mathrm{~mm}$ at Nakhon Ratchasima to $1,541 \mathrm{~mm}$ at Ubon Ratchathani and tended 
Table 1. Average and coefficient of variation, and regression coefficient of the first regression equation in rainfall during recent 20 years at different locations in Thailand

\begin{tabular}{|c|c|c|c|c|c|c|c|c|c|c|c|c|c|c|c|}
\hline \multirow{2}{*}{ Division } & \multirow{2}{*}{ Location } & \multirow{2}{*}{$\begin{array}{l}\text { Latitude- } \\
\text { Longitude }^{\mathrm{a}}\end{array}$} & \multirow{2}{*}{$\begin{array}{l}\text { Dura- } \\
\text { tion }\end{array}$} & \multicolumn{3}{|c|}{ Annual ${ }^{b}$} & \multicolumn{3}{|c|}{$\begin{array}{l}\text { Dry-season }{ }^{\circ} \\
\text { (November to February) }\end{array}$} & \multicolumn{3}{|c|}{$\begin{array}{l}\text { Premonsoon-season } \\
\text { (March to May) }\end{array}$} & \multicolumn{3}{|c|}{$\begin{array}{l}\text { Monsoon-season }{ }^{b} \\
\text { (June to October) }\end{array}$} \\
\hline & & & & $\begin{array}{l}\text { Ave } \\
(\mathrm{mm})\end{array}$ & $\begin{array}{l}\text { CV } \\
(\%)\end{array}$ & $\begin{array}{c}\mathrm{RC} \\
\left(\mathrm{mm}^{\mathrm{year}}{ }^{-1}\right)\end{array}$ & $\begin{array}{l}\text { Ave } \\
(\mathrm{mm})\end{array}$ & $\begin{array}{l}\mathrm{CV} \\
(\%)\end{array}$ & $\begin{array}{c}\mathrm{RC} \\
\left.\left(\mathrm{mm}^{\mathrm{year}}\right)^{-1}\right)\end{array}$ & $\begin{array}{l}\text { Ave } \\
(\mathrm{mm})\end{array}$ & $\begin{array}{l}\mathrm{CV} \\
(\%)\end{array}$ & $\begin{array}{c}\mathrm{RC} \\
\left(\mathrm{mm} \text { year }^{-1}\right)\end{array}$ & $\begin{array}{l}\text { Ave } \\
(\mathrm{mm})\end{array}$ & $\begin{array}{l}\mathrm{CV} \\
(\%)\end{array}$ & $\begin{array}{c}\mathrm{RC} \\
\left(\mathrm{mm} \text { year }^{-1}\right)\end{array}$ \\
\hline \multirow[t]{5}{*}{ North } & $\begin{array}{l}\text { Mae Hong Song, } \\
\text { Rice Exp. Sta. }\end{array}$ & $\begin{array}{l}19.18 \mathrm{~N}- \\
98.01 \mathrm{E}\end{array}$ & $\begin{array}{l}1985 \\
\text { to }\end{array}$ & 1311 & 16 & 6.4 & 73 & 68 & -5.3 & 295 & 50 & 13.4 & 945 & 16 & -2.9 \\
\hline & $\begin{array}{l}\text { Mae Jo, } \\
\text { Field Crop Res. } \\
\text { Center }\end{array}$ & $\begin{array}{l}18.55 \mathrm{~N}- \\
99.00 \mathrm{E}\end{array}$ & 2001 & 1048 & 17 & -3.5 & 71 & 81 & -6.0 & 227 & 53 & 5.5 & 752 & 14 & -3.2 \\
\hline & $\begin{array}{l}\text { Nan, } \\
\text { Horticultural } \\
\text { Res. Exp. Sta. }\end{array}$ & $\begin{array}{l}18.47 \mathrm{~N}- \\
100.50 \mathrm{E}\end{array}$ & & 1289 & 16 & $22.8^{*}$ & 54 & 83 & -1.1 & 309 & 36 & 1.4 & 929 & 19 & $22.9^{* *}$ \\
\hline & $\begin{array}{l}\text { Nakhon Sawan, } \\
\text { Field Crop Res. } \\
\text { Center }\end{array}$ & $\begin{array}{l}15.47 \mathrm{~N}- \\
100.04 \mathrm{E}\end{array}$ & & 1201 & 21 & 7.1 & 57 & 122 & -2.4 & 295 & 48 & 10.1 & 850 & 18 & -0.1 \\
\hline & $\begin{array}{l}\text { Phetchabun, } \\
\text { Field Crop Exp. } \\
\text { Sta. }\end{array}$ & $\begin{array}{l}16.25 \mathrm{~N}- \\
101.08 \mathrm{E}\end{array}$ & & 1089 & 22 & 6.8 & 35 & 81 & 5.9 & 307 & 32 & 3.5 & 740 & 24 & 5.9 \\
\hline \multirow[t]{6}{*}{$\begin{array}{l}\text { North- } \\
\text { east }\end{array}$} & $\begin{array}{l}\text { Maha Sarakham, } \\
\text { Field Crop Exp. } \\
\text { Sta. }\end{array}$ & $\begin{array}{l}16.12 \mathrm{~N} \\
103.16 \mathrm{E}\end{array}$ & $\begin{array}{l}1985 \\
\text { to } \\
2001\end{array}$ & 1248 & 13 & 10.8 & 34 & 68 & 1.1 & 312 & 43 & 6.9 & 899 & 15 & 3.8 \\
\hline & $\begin{array}{l}\text { Kalasin, } \\
\text { Field Crop Exp. } \\
\text { Sta. }\end{array}$ & $\begin{array}{l}16.29 \mathrm{~N}- \\
103.30 \mathrm{E}\end{array}$ & & 1071 & 18 & 6.0 & 31 & 86 & 0.4 & 252 & 34 & 3.1 & 785 & 21 & 3.2 \\
\hline & $\begin{array}{l}\text { Chaiyaphum, } \\
\text { Sericulture Exp. } \\
\text { Sta. }\end{array}$ & $\begin{array}{l}15.46 \mathrm{~N}- \\
101.55 \mathrm{E}\end{array}$ & & 1100 & 17 & 4.9 & 33 & 84 & 1.0 & 281 & 26 & 5.9 & 788 & 22 & -1.8 \\
\hline & $\begin{array}{l}\text { Nakhon } \\
\text { Ratchasima } \\
\text { (Korat) }\end{array}$ & $\begin{array}{l}15.00 \mathrm{~N}- \\
102.06 \mathrm{E}\end{array}$ & & 833 & 26 & 2.8 & 37 & 111 & -1.5 & 200 & 38 & 3.2 & 597 & 29 & 0.8 \\
\hline & $\begin{array}{l}\text { Roi Et, } \\
\text { Field Crop Exp. } \\
\text { Sta. }\end{array}$ & $\begin{array}{l}16.04 \mathrm{~N}- \\
103.67 \mathrm{E}\end{array}$ & & 1292 & 13 & 13.0 & 30 & 84 & 0.4 & 287 & 32 & $10.1^{*}$ & 964 & 12 & 0.2 \\
\hline & $\begin{array}{l}\text { Ubon } \\
\text { Ratchathani, } \\
\text { Rice Res. Center }\end{array}$ & $\begin{array}{l}15.24 \mathrm{~N}- \\
104.88 \mathrm{E}\end{array}$ & & 1541 & 15 & 2.8 & 41 & 90 & 2.2 & 338 & 41 & 9.2 & 1150 & 19 & -7.4 \\
\hline \multirow[t]{2}{*}{ West } & $\begin{array}{l}\text { Suphan Buri, } \\
\text { Rice Exp. Sta. }\end{array}$ & $\begin{array}{l}14.45 \mathrm{~N}- \\
100.12 \mathrm{E}\end{array}$ & $\begin{array}{l}1985 \\
\text { to } \\
2001\end{array}$ & 1006 & 25 & -5.6 & 83 & 110 & -0.7 & 195 & 48 & 4.0 & 728 & 29 & -7.4 \\
\hline & $\begin{array}{l}\text { Phra Phutthabat, } \\
\text { Field Crop Exp. } \\
\text { Sta. }\end{array}$ & $\begin{array}{l}14.44 \mathrm{~N}- \\
100.36 \mathrm{E}\end{array}$ & & 1265 & 18 & 9.1 & 45 & 91 & 1.8 & 327 & 46 & 10.6 & 892 & 17 & -3.4 \\
\hline \multirow[t]{3}{*}{ South } & $\begin{array}{l}\text { Surat Thani, } \\
\text { Oil Palm Res. } \\
\text { Center }\end{array}$ & $\begin{array}{l}9.09 \mathrm{~N}- \\
99.20 \mathrm{E}\end{array}$ & $\begin{array}{l}1992 \\
\text { to } \\
2001\end{array}$ & 2125 & 16 & -24.3 & 844 & 35 & 3.0 & 332 & 41 & 16.9 & 987 & 30 & -34.2 \\
\hline & $\begin{array}{l}\text { Krabi, } \\
\text { Rice Exp. Sta. }\end{array}$ & $\begin{array}{l}8.04 \mathrm{~N}- \\
98.52 \mathrm{E} \\
\end{array}$ & & 2157 & 13 & 38.2 & 373 & 23 & $27.9^{* *}$ & 438 & 32 & 30.2 & 1358 & 19 & -8.4 \\
\hline & $\begin{array}{l}\text { Songkhla, } \\
\text { Rubber Res. } \\
\text { Center }\end{array}$ & $\begin{array}{l}7.12 \mathrm{~N}- \\
100.35 \mathrm{E}\end{array}$ & $\begin{array}{l}1985 \\
\text { to } \\
2001\end{array}$ & 1947 & 22 & $50.3^{*}$ & 895 & 37 & $47.0^{* *}$ & 303 & 43 & 3.4 & 764 & 20 & 8.4 \\
\hline
\end{tabular}

${ }^{\text {a }}$ Degree $\left({ }^{\circ}\right)$ is not shown in the expression of latitude-longitude.

${ }^{b}$ Ave: average; CV: coefficient of variation; RC: regression coefficient in the first regression equation.

** and ${ }^{*}$ mean significance at $1 \%$ and $5 \%$ levels, respectively. 
to increase from the central region to the eastern and northwestern regions. The average rainfall in the dry-season (November to February) was in a range between 35 and $73 \mathrm{~mm}$ in the north division and between 30 and $41 \mathrm{~mm}$ in the northeast division with the large annual variability, as expected from the relatively high coefficient of variation, and occupied only 3.2 to $6.8 \%$ and 2.3 to $4.4 \%$, respectively, of the mean annual rainfall. The regression coefficient of the first regression equation, as an index of the rainfall trend, was mostly positive in the annual rainfall, ranging from 2.8 to $22.8 \mathrm{~mm}^{-1} \mathrm{ear}^{-1}$, except for Mae Jo, although it was only significant for Nan at $5 \%$ level. The positive trend was generally suggested to the premonsoon-season rainfall, but the significant trends were only noticed at Roi Et in the premonsoon-season rainfall and at Nan in the monsoon-season rainfall.

Mean annual rainfall of 2 locations in the west division of Thailand was 1,006 and $1,265 \mathrm{~mm}$ and within the rainfall range observed in the north and northeast divisions. The average rainfall in the dry season was 83 and $45 \mathrm{~mm}$ with occupation of 8.3 and $3.6 \%$, respectively, of the mean annual rainfall. The positive trend in the premonsoon-season rainfall and the negative trend in the monsoon-season rainfall were suggested, although the regression coefficients were all insignificant. In general, features and trends of the annual and seasonal rainfall in the west division were considered similar to those in the north and northeast divisions.

Tropical rainforest climate (Region II of humid to perhumid equatorial climate by Kawaguchi and Kyuma (1977)) is prevailing in the south division of Thailand. Mean annual rainfall of 3 locations in the south division was in a range of 1,947 to 2,157 mm and considerably larger than that of the other divisions. Rainfall distribution was rather uniform throughout the year at Surat Thani and Songkhla located along the eastern side of the peninsula, whereas it was a little concentrated in the season of June to October at Krabi located along the western side of the peninsula. Concerning the rainfall trend, the negative but insignificant trends in the annual and seasonal (June to October) rainfall were shown at Surat Thani. However, the positive and significant trend in the seasonal (November to February) rainfall was indicated for Songkhla and Krabi with regression-coefficients of 47.0 and $27.9 \mathrm{~mm}^{-1}$ yar $^{-1}$, respectively. The significantly positive trend was also indicated in the annual rainfall of Songkhla with a regression-coefficient of $50.3 \mathrm{~mm}$ year ${ }^{-1}$.

\section{Bangladesh and Viet Nam}

Results for Bangladesh and Viet Nam are shown in Table 2. Major 4 cities of Dhaka, Sylhet, Rajshahi, and Chittagong in Bangladesh, and Ha Noi, the capital, in Viet Nam were selected for the rainfall analysis. These cities are distributed between $21.0^{\circ} \mathrm{N}$ and $25.4^{\circ} \mathrm{N}$ around the Tropic of Cancer. In Bangladesh, mean annual rainfall increased from $1,526 \mathrm{~mm}$ at Rajshahi (western region) to $4,244 \mathrm{~mm}$ at Sylhet (northeastern region) through 2,154 mm at Dhaka (central region) and 2,941 mm at Chittagong (southeastern region). The whole country of Bangladesh is under tropical to subtropical monsoon climate (Kawaguchi and Kyuma, 1977; mainly Region VII with IV and VIII according to their climatic region). Percentage of the average rainfall in the dry season (November to March) to the mean annual rainfall was in a narrow range of 4.8 to $7.0 \%$ for the 4 locations, although the amount varied from $73 \mathrm{~mm}$ at Rajshahi to $254 \mathrm{~mm}$ at Sylhet. The 
Table 2. Average and coefficient of variation, and regression coefficient of the first regression equation in rainfall during recent 20 years at different locations in Bangladesh and Viet Nam

\begin{tabular}{|c|c|c|c|c|c|c|c|c|c|c|c|c|c|c|c|}
\hline \multirow{2}{*}{ Country } & \multirow{2}{*}{ Location } & \multirow{2}{*}{$\begin{array}{l}\text { Latitude- } \\
\text { Longitude }\end{array}$} & \multirow{2}{*}{$\begin{array}{l}\text { Dura- } \\
\text { tion }\end{array}$} & \multicolumn{3}{|c|}{ Annual ${ }^{b}$} & \multicolumn{3}{|c|}{$\begin{array}{l}\text { Dry-season } \\
\text { (November to March) }\end{array}$} & \multicolumn{3}{|c|}{$\begin{array}{l}\text { Premonsoon-season } \\
\text { (April to May) }\end{array}$} & \multicolumn{3}{|c|}{$\begin{array}{l}\text { Monsoon-season } \\
\text { (June to October) }\end{array}$} \\
\hline & & & & $\begin{array}{l}\text { Ave } \\
(\mathrm{mm})\end{array}$ & $\begin{array}{l}\text { CV } \\
(\%)\end{array}$ & $\begin{array}{c}\mathrm{RC} \\
\left(\mathrm{mm}^{-} \text {year-1) }\right.\end{array}$ & $\begin{array}{l}\text { Ave } \\
\text { (mm) }\end{array}$ & $\begin{array}{l}\text { CV } \\
(\%)\end{array}$ & $\begin{array}{c}\mathrm{RC} \\
\left(\mathrm{mm}^{\mathrm{m}} \text { year }{ }^{-1}\right)\end{array}$ & $\begin{array}{l}\text { Ave } \\
\text { (mm) }\end{array}$ & $\begin{array}{l}\text { CV } \\
(\%)\end{array}$ & $\begin{array}{c}\mathrm{RC} \\
\left(\mathrm{mm}^{\mathrm{n}} \text { year }^{-1}\right)\end{array}$ & $\begin{array}{l}\text { Ave } \\
\text { (mm) }\end{array}$ & $\begin{array}{l}\mathrm{CV} \\
(\%)\end{array}$ & $\begin{array}{c}\mathrm{RC} \\
\left(\mathrm{mm}^{\mathrm{year}}{ }^{-1}\right)\end{array}$ \\
\hline \multirow[t]{4}{*}{ Bangladesh } & Dhaka & $\begin{array}{l}23.42 \mathrm{~N}- \\
90.22 \mathrm{E}\end{array}$ & $\begin{array}{l}1981 \\
\text { to }\end{array}$ & 2154 & 21 & -15.3 & 151 & 46 & -2.1 & 495 & 38 & -3.8 & 1507 & 22 & -8.4 \\
\hline & Sylhet & $\begin{array}{l}25.43 \mathrm{~N}- \\
91.51 \mathrm{E}\end{array}$ & 2001 & 4244 & 15 & -39.3 & 254 & 56 & -1.6 & 928 & 31 & -17.3 & 3063 & 17 & -21.1 \\
\hline & Rajshahi & $\begin{array}{l}24.24 \mathrm{~N}- \\
88.40 \mathrm{E}\end{array}$ & & 1526 & 21 & -1.4 & 73 & 59 & -0.5 & 215 & 48 & -6.3 & 1235 & 22 & 7.0 \\
\hline & Chittagong & $\begin{array}{l}22.20 \mathrm{~N}- \\
91.48 \mathrm{E}\end{array}$ & $\begin{array}{l}1981 \text { to } \\
2000\end{array}$ & 2941 & 15 & 11.5 & 167 & 70 & 4.1 & 432 & 49 & 7.6 & 2327 & 18 & 6.2 \\
\hline Viet Nam & $\mathrm{Ha} \mathrm{Noi}$ & $\begin{array}{l}21.01 \mathrm{~N}- \\
105.52 \mathrm{E}\end{array}$ & $\begin{array}{l}1980 \text { to } \\
1999\end{array}$ & 1596 & 30 & -19.2 & 100 & 84 & 9.2 & 265 & 57 & -3.8 & 1117 & 32 & -6.1 \\
\hline
\end{tabular}

a Degree $\left({ }^{\circ}\right)$ is not shown in the expression of latitude-longitude.

${ }^{b}$ Ave: average; CV: coefficient of variation; RC: regression coefficient in the first regression equation.

negative trends at Dhaka and Sylhet while the positive trends at Chittagong in the annual rainfall and the rainfall in the 3 seasons were indicated, but all trends were insignificant. The negative but insignificant trend in the premonsoon-season rainfall was indicated for Rajshahi; rainfall in the dry season is already in a insufficient level in the west region, and the decrease in rainfall in the premonsoon season has a severe damage on the cultivation of rabi crops and aus rice without irrigation.

Ha Noi in Viet Nam is under subtropical monsoon climate (Kawaguchi and Kyuma, 1977; Region VIII according to their climatic region). Mean annual rainfall was $1,596 \mathrm{~mm}$. The average rainfall in the dry season (November to March) was $84 \mathrm{~mm}$ with occupation of $5.3 \%$ in the mean annual rainfall. The negative trends in the annual rainfall and the rainfall in the premonsoon and monsoon seasons and the positive trend in the rainfall in the dry season were indicated, although all trends were not significant.

\section{Indonesia}

Results for Indonesia are presented in Table 3. Seven locations were selected from major 3 islands of Sumatra, Kalimantan, and Java in Indonesia. These locations are under tropical rainforest climate and belong to humid (Region I) and perhumid (Region III) equatorial climates according to the climatic region by Kawaguchi and Kyuma (1977). Mean annual rainfall was higher for Tabing (Padang) and Darmaga (Bogor) under perhumid equatorial climate, with values of 3,717 and $3,775 \mathrm{~mm}$, respectively, than for Polonia (Medan), Sepinggan (Balikpapan), Jakarta, Bandung, and Juanda (Surabaya) having mean annual rainfall ranging from 1,759 to $2,422 \mathrm{~mm}$. The average rainfall was almost similar between the seasons of April to September and of October to March at Polonia, Tabing, Sepinggan, and Darmaga, whereas it was considerably higher for the season of October to March than for the season of April to September at Jakarta, Bandung, and Juanda, as expected from the example of the rainfall distribution shown to Region I by 
Table 3. Average and coefficient of variation, and regression coefficient of the first regression equation in rainfall during recent 20 years at different locations in Indonesia

\begin{tabular}{|c|c|c|c|c|c|c|c|c|c|c|c|c|}
\hline \multirow[t]{2}{*}{ Island } & \multirow[t]{2}{*}{ Location } & \multirow[t]{2}{*}{$\begin{array}{l}\text { Latitude- } \\
\text { Longitude }\end{array}$} & \multirow{2}{*}{$\begin{array}{l}\text { Dura- } \\
\text { tion }\end{array}$} & \multicolumn{3}{|c|}{ Annual ${ }^{b}$} & \multicolumn{3}{|c|}{$\begin{array}{l}\text { Dry-season } \\
\text { (April to September) }\end{array}$} & \multicolumn{3}{|c|}{$\begin{array}{l}\text { Rainy-season }{ }^{b} \\
\text { (October to March) }\end{array}$} \\
\hline & & & & $\begin{array}{l}\text { Ave } \\
(\mathrm{mm})\end{array}$ & $\begin{array}{l}\text { CV } \\
(\%)\end{array}$ & $\begin{array}{c}\mathrm{RC} \\
\left(\text { mm year-1 }^{-1}\right)\end{array}$ & $\begin{array}{l}\text { Ave } \\
(\mathrm{mm})\end{array}$ & $\begin{array}{l}\text { CV } \\
(\%)\end{array}$ & $\begin{array}{c}\mathrm{RC} \\
\left(\mathrm{mm}^{2} \text { year-1) }\right.\end{array}$ & $\begin{array}{l}\text { Ave } \\
\text { (mm) }\end{array}$ & $\begin{array}{l}\mathrm{CV} \\
(\%)\end{array}$ & $\begin{array}{c}\mathrm{RC} \\
\left(\mathrm{mm}^{2} \text { year }^{-1}\right)\end{array}$ \\
\hline \multirow[t]{2}{*}{ Sumatra } & $\begin{array}{l}\text { Polonia }^{c} \\
\text { (Medan) }\end{array}$ & $\begin{array}{l}3.34 \mathrm{~N}- \\
98.41 \mathrm{E}\end{array}$ & \multirow{2}{*}{$\begin{array}{l}1970 \\
\text { to } \\
1997\end{array}$} & 2132 & 16 & -1.7 & 1056 & 27 & 2.5 & 1085 & 22 & -4.9 \\
\hline & $\begin{array}{l}\text { Tabing } \\
\text { (Padang) }\end{array}$ & $\begin{array}{l}0.53 \mathrm{~S}- \\
100.21 \mathrm{E}\end{array}$ & & 3717 & 22 & $-48.2^{*}$ & 1722 & 28 & $-36.1^{* *}$ & 2028 & 23 & -5.5 \\
\hline Kalimantan & $\begin{array}{l}\text { Sepinggan } \\
\text { (Balikpapan) }\end{array}$ & $\begin{array}{l}1.16 \mathrm{~S}- \\
116.54 \mathrm{E}\end{array}$ & $\begin{array}{l}1971 \text { to } \\
1997\end{array}$ & 2422 & 20 & -5.8 & 1210 & 28 & -5.9 & 1233 & 20 & 2.0 \\
\hline \multirow[t]{4}{*}{ Java } & Jakarta & $\begin{array}{l}6.10 \mathrm{~S}- \\
106.49 \mathrm{E} \\
\end{array}$ & $\begin{array}{l}1970 \\
\text { to }\end{array}$ & 1895 & 19 & $-17.8^{*}$ & 522 & 32 & -0.5 & 1376 & 22 & $-15.7^{*}$ \\
\hline & Bandung & $\begin{array}{l}6.55 \mathrm{~S}- \\
107.36 \mathrm{E}\end{array}$ & 1997 & 1761 & 30 & -41.5 & 627 & 43 & -17.4 & 1085 & 22 & -20.3 \\
\hline & $\begin{array}{l}\text { Darmaga }^{c} \\
\text { (Bogor) }\end{array}$ & $\begin{array}{l}6.30 \mathrm{~S}- \\
106.45 \mathrm{E}\end{array}$ & $\begin{array}{l}1971 \text { to } \\
1997\end{array}$ & 3775 & 16 & -42.0 & 1670 & 29 & -34.5 & 2002 & 16 & -12.1 \\
\hline & $\begin{array}{l}\text { Juanda }^{c} \\
\text { (Surabaya) }\end{array}$ & $\begin{array}{l}7.13 \mathrm{~S}- \\
112.43 \mathrm{E}\end{array}$ & $\begin{array}{l}1972 \text { to } \\
1997\end{array}$ & 1759 & 26 & 10.0 & 449 & 45 & 0.8 & 1339 & 23 & 2.3 \\
\hline
\end{tabular}

${ }^{\text {a }}$ Degree $\left({ }^{\circ}\right)$ is not shown in the expression of latitude-longitude.

${ }^{\mathrm{b}}$ Ave: average; CV: coefficient of variation; RC: regression coefficient in the first regression equation.

' Significance of the regression coefficient could not be calculated for Polonia, Bandung, Darmaga, and

Juanda due to partial missing of monthly rainfall data.

$* *$ and $*$ mean significance at $1 \%$ and $5 \%$ levels, respectively.

Kawaguchi and Kyuma (1977).

Concerning the rainfall trend, Tabing in Sumatra Island indicated the significantly negative trends in the annual and seasonal (April to September) rainfall with regression-coefficients of -48.2 and $-36.1 \mathrm{~mm}$ year $^{-1}$, respectively. Jakarta in Java Island also gave the significantly negative trends in the annual and seasonal (October to March) rainfall, and the corresponding regression-coefficients were -17.8 and $-15.7 \mathrm{~mm}_{\text {year }}{ }^{-1}$. No significant trend in rainfall was recognized for Sepinggan in Kalimantan Island. Significance of the regression coefficient could not be verified to the other 4 locations due to partial missing of monthly rainfall data, but the negative trends in the annual and seasonal rainfall were strongly suggested for Bandung and Darmaga in Java Island but not for Polonia in Sumatra Island and Juanda in Java Island, based on the magnitude of their regression-coefficients. In Java Island, Jakarta, Bandung, and Darmaga are located in the western half while Juanda is in the eastern half of the island. In Sumatra Island, Polonia is located in the side along the Straits of Malacca while Tabing is in the side along the Indian Ocean. No significantly positive trend was found in Indonesia, different from Peninsula Thailand.

\section{CONCLUSIONS}

Significant trends in annual and/or seasonal rainfall during recent 20 years were identified at several locations under tropical rainforest climate in Thailand and Indonesia. 
The positive rainfall trend was recognized at locations in Peninsula Thailand, whereas the negative rainfall trend was identified at locations along the side of the Indian Ocean of Sumatra Island and in the western half of Java Island. Under tropical to subtropical monsoon climate, very few locations showed the significantly positive trend in the annual and/or seasonal rainfall in Thailand.

\section{REFERENCES}

Egashira, K. 2002 Present situation of rainfall in tropical Asia - A case in Madhupur Tract of Bangladesh. Jpn. J. Soil Sci. Plant Nutr., 73: 841 (in Japanese)

Egashira, K. and A. J. M. S. Karim 2001 Recent rainfall conditions in Madhupur Tract of Bangladesh. J. Fac. Agric. Kyushu Univ., 46: 69-74

Kawaguchi, K. and K. Kyuma 1977 Paddy Soils in Tropical Asia. The University Press of Hawaii, Honolulu, pp. 10-25

Ohno, H., Y. Ishigooka, S. Goto, H. Toritani, and T. Kuwagata 2003 Impact of global warming on agricultural and forest ecosystem. 2. Influence on water resources. Jpn. J. Soil Sci. Plant Nutr., 74: 85-92 (in Japanese) 